\section{Industrial Research in Scotland}

THe Federation of British Industries has arranged a one-day conference to be held in the Merchant's Hall, Glasgow, on Friday, April 25. Mr. Alexander Johnston, chairman of the Scottish Regional Council of the Federation, will preside at the morning session, when Sir James Lithgow will give the opening address. Papers on research in Scotland's major industries will be read by Mr. W. Barr (on steel), Sir Wilfrid Ayre (on shipbuilding), and Mr. W. G. Marskell (on heavy engineering). The chairman of the afternoon session will be Prof. T. Alty, of the University of Glasgow, and the following five papers will be given : research as a means of providing new industries, by Dr. J. W. MeDavid; chemical research for Scottish industry, by Prof. W. M. Cumming (Royal Technical College, Glasgow) ; Scotland's mineral raw materials, by Mr. T. H Whitehead (Geological Survey of Great Britain); research in the light engineering industries, by Mr. J. N. Toothill; the individual Scottish firm and its application of research, by Prof. R. Hay (Royal Technical College, Glasgow). Sir Steven Bilsland, chairman of the Scottish Council, will sum up the discussion and addresses. Admission to the Conference is free, and tickets can be obtained either from the F.B.I. Scottish Office, 142, St. Vincent Street, Glasgow, C.2, or from the F.B.I. Industrial Research Secretariat, 21, Tothill Street, London, S.W.1.

\section{Acoustics Group of the Physical Society}

THe Acoustics Group of the Physical Society has been formed at an inaugural meeting held at the Royal Institute of British Architects. Mr. H. L. Kirke was in the chair and Dr. Alex Wood gave an address entitled "The Contribution of Acoustical Science to Allied Studies". The meeting was attended by some 170 persons. The principal object of the Group is to provide an opportunity for the very varied types of workers engaged on acoustical problems to meet and discuss the scientific and technical implications of their work. The officers and committee of the Group, elected at the inaugural meeting to serve for the year 1947-48, are as follows: Chairman : Mr. H. L. Kirke; Vice-Chairman: Dr. A. Wood; Joint Secretaries : Messrs. W. A. Allen and A. T. Pickles; Committee : Messrs. H. Bagenal, R. S. Dadson, Dr. C. S. Hallpike, J. McLaren, B. C. Sewell, W. West, Dr. A. B. Wood and Dr. W. Greenhouse Allt. Membership of the Group is open both to members and also to non-members of the Physical Society. It is hoped to arrange for some six meetings a year, including at least one special summer meeting, which will take the form of a symposium covering a particular aspect of acoustical investigation ; reprints of papers will be circulated to members when available, and it is hoped to arrange for research panels on special topics. For further particulars application should be made to the Joint Honorary Secretaries, at the Physical Society, 1, Lowther Gardens, Prince Consort Road, London, S.W.7.

\section{Announcements}

Prof. F. J. M. Stratton, professor of astrophysics in the University of Cambridge, and Prof. A. Dauvil. lier, of the École supérieure d'Électricite, have been elected Correspondants for the Section of Astronomy, and Prof. P. M. S. Blackett, Langworthy professor of physies in the University of Manchester, and Prof. Emile Henriot, professor of physies in the University of Brussels, have been elected Correspondants for the Section of General Physics, of the Paris Academy of Sciences.

The Holweck Prize for 1947 of the Physical Society and the Medaille Holweck of the Société Française de Physique have been awarded to Prof. E. N. da C. Andrade, Quain professor of physics in the University of London, in recognition of his experimental investigations on the solid and liquid states.

Mr. A. J. Philpot, director of the British Scientific Instrument Research Association, has been appointed director of the Scientific Instrument Manufacturers' Association of Great Britain, Ltd. He will continue as director of the Research Association, and will work from the Association's offices at 26 Russell Square, London, W.C.I. Mr. Philpot will speak on "Scientific Instrument Manufacture and the Nation" at the Northampton Polytechnic, London, E.C.1, on April 24 at 7.30 p.m.; admission is free, by ticket obtainable from the Polytechnic.

DR. J. L. B. Sмiтh, for many years in charge of organic chemistry at Rhodes University College, Grahamstown, has recently resigned to be appointed research professor in ichthyology in the College. Dr. Smith is already well known for his ichthyological researches, which included the announcement in 1939 of the discovery of a living Cœlacanthid fish (see Nature, 143, 455 ; 1939). Dr. Smith has also been awarded a research fellowship in ichthyology by the South African Council of Scientific and Industrial Research.

Mr. W. L. HALL has been appointed chief officer of the Liaison Department of the British NonFerrous Metals Research Association, in succession to Mr. W. C. F. Hessenberg, who has been appointed head of the Mechanical Working Division of the British Iron and Steel Research Association. Mr. Hall graduated from the Royal School of Mines with a first-class honours degree in 1936. After two years experience in a steel works, he joined the research staff of the British Non-Ferrous Metals Research Association in 1938, working on galvanizing, stress corrosion of light alloys and the properties of aluminium-magnesium alloys; he was transferred to the Liaison Department in 1944.

Sir Wallace Akers, a director of Imperial Chemical Industries, Ltd., will deliver the May lecture of the Institute of Metals on May 21 at 6 p.m.; he will speak on "Metallurgical Problems involved in the Generation of Useful Power from Atomic Energy". Admission is by ticket obtainable from the Institute.

The Council of the Royal Society will shortly consider the nomination of not more than three marine biologists to visit the Roscoff Biological Station (Finistère) during the summer months. Those wishing to be considered in this connexion should communicate with the Assistant Secretary of the Royal Society, Burlington House, London, W.1, not later than May 7, and should submit a brief statement of the investigation which it is proposed to carry out, together with an indication of the inclusive dates of the visit.

A ONE-DAY school on atomic energy for journalists arranged by the Atomic Scientists Assaciation will be held in the Embryology Theatre, University College, Gower Street, W.C.1, on April 26, 1947. The speakers will be Prof. H. S. W. Massey, Prof. M. H. L. Pryce and Prof. R. E. Peierls. 